\title{
Prevention of Computer Damage
}

\author{
Luay Abdulwahid Shihab
}

Department of Branch of Basic Science, College of Nursing, University of Basrah, Basrah, Iraq

DOI: $10.36347 /$ sjet.2020.v08i04.004

| Received: 27.03.2020 | Accepted: 03.04.2020 | Published: 28.04.2020

*Corresponding author: Luay Abdulwahid Shihab

Abstract

Through the discussion of the study, there are many negative aspects, including the occurrence of a computer with health damages that are damaged in the user's body, so he must take health measures to protect the members of the body from the harm of using the computer through the use of filtered eyes to protect the eye and sit in a normal straight way with daily exercise and take a break Intermittent.

Keywords: Prevention, computer, damage.

Copyright @ 2020: This is an open-access article distributed under the terms of the Creative Commons Attribution license which permits unrestricted use, distribution, and reproduction in any medium for non-commercial use (NonCommercial, or CC-BY-NC) provided the original author and source are credited.

\section{INTRODUCTION}

Computers have become everything in life from education, health, business and homes through the use of the Internet The computer is one of the most important inventions that have developed the world, which is the main reason for the great development that occurred in recent years and the computer is known as a programmed device to perform rapid operations or to store information and retrieve it at any time, either A convention known as a machine programmed to perform specific and specific functions and tasks [1]. There are some studies at a university about the number of computer users, among which the study was conducted in the research was focused on the microbial studies of pathogenic bacteria on computers mice and keyboards collected from different computer labs and office of College of Nursing, University of Basrah, Iraq. .The samples were collected in two groups, first group $(\mathrm{n}=50)$ from computer keyboards and mice were collected and second group $(\mathrm{n}=50)$ from staff and student that user computer daily after sterilization hands before using the computer [2].

Although there are many positives in the computer, there are also many negatives, including damage to the eyes, as sitting for long hours in front of the computer without obtaining rest leads to fatigue, exhaustion and fatigue in the eye. Exposing neck muscles to problems causing pain due to long sitting in front of a computer screen. Isolating a computer user from the outside world and surrounding it, because it takes a long time in his life at the expense of carrying out other activities. Feeling headache and aches in the head. Unemployment The concept of unemployment emerged as one of the computer negatives, because it has become a common practice to rely more on computer and computer programs and machines programmed via the computer, so the need for workers to be present in companies or factories has decreased, so the unemployment rate has increased. Wasting time and energy: A lot of people use computers without a positive goal, and they play video games continuously and very long, and they talk for a long time also with their friends, and all of this wasted time and energy because it allowed the opportunity to do such acts in an easy and simple way at any time, The biggest example of wasting time is what young people currently spend time on social media, and other applications that allow different types of social communication between members of society. Computer crimes: Some people who use the computer for negative and harmful activities have appeared, such as stealing bank account details, stealing other people's money, or blackmailing people by stealing their photos or posting them on social media, and other thefts that target all types of data And the information available on the Internet. Violation of privacy: There are some sites that ask the user to sign a privacy policy (such as Facebook and Twitter). Through this, these sites can access some conversations or some personal pictures, and use them for their own marketing sometimes [3].

\section{Computer damage}

1. The effect of computers on the eye

Computer rays are X-rays, electromagnetic radiation, ultraviolet rays and infrared rays, which lead to a lack of melatonin, which affects the body's immunity. 
Computer rays affect neurotransmitters, and this reduces the ability to focus, which affects the activities of the person.

\section{Eye strain}

Low vision due to exposure to continuous lighting. While sitting at the computer, the eye may not blink, causing it to dry out.

\section{Back and shoulder pain}

Long sitting and crouching towards the computer screen cause great pressure on the shoulders and spine, and it prevents blood and nutrients from flowing between the vertebrae, and this leads to severe pain in the back and shoulders area, and increases the risk of disc and other spinal diseases.

\section{Hips atrophy}

Hips need permanent movement in order to maintain their flexibility to perform their function in balancing the body, and permanent sitting and lack of movement leads to their atrophy with time, and this reduces their ability to move in all directions.

\section{Obesity} obesity.

Sitting for a long time on the computer causes

\section{Computer Internet addiction}

Sitting for a long time on the computer causes addiction to the computer due to the fun [4].

\section{Prevention of computer damage:}

1. Use filtered glasses to protect the eyes from computer radiation.

It is possible to determine the level of brightness and illumination of the screen and reduce them, which reduces eye fatigue and eye fatigue from computer rays, and this for 5 minutes every hour, which reduces eye fatigue.

Resorting to glasses that help to preserve the eyesight from the computer's rays and reverse the radiation from the screen

2. The sitting should be straight and without curvature.

3. Not to sit for long periods of time, and you should rest every hour.

4. Exercise should be practiced daily to frighten obesity and to move the body parts.

5. You should not sit for a long time and practice other hobbies, even from the sitting hours on the computer. Sitting on a long computer causes increased introversion and depression.

\section{REFFRENCE}

1. What are all of the disadvantages of using a computer, www.computerhope.com. 29-12-2017.

2. Khulood Abdul Kareem, Luaay Abdul Wahed Shihab, Genetic Study for icaAD Gene to Staphylococcus Aureus Isolated from Different Part of Computer, International Journal of Advanced Research in Computer Science and Software Engineering January. 2016, 6(1): 97-100.

3. Lai CC, Kritsonis WA. The advantages and disadvantages of computer technology in second language acquisition. Online Submission. 2006;3(1).

4. Dina AT, Ciornei SI. The advantages and disadvantages of computer assisted language learning and teaching for foreign languages. Procedia-Social and Behavioral Sciences. 2013 Apr $15 ; 76: 248-52$ 